\title{
Boar seminal plasma: current insights on its potential role for assisted reproductive technologies in swine
}

\author{
Inmaculada Parrilla1,2* (D), Emilio Arsenio Martinez ${ }^{1,2}$ (D), Maria Antonia Gil ${ }^{1,2}$ (D), Cristina Cuello ${ }^{1,2}$ (D), \\ Jordi Roca ${ }^{1,2}$ (D) , Heriberto Rodriguez-Martinez ${ }^{3}$ (D), Cristina Alicia Martinez ${ }^{3}$ (D) \\ 'Departmento de Medicina y Cirugía Animal, Facultad de Veterinaria, Campus de de Excelencia International “Campus Mare \\ Nostrum", Universidad de Murcia, Murcia, Spain \\ ${ }^{2}$ Instituto Murciano de Investigación Biosanitaria, Campus de Ciencias de la Salud, Murcia, Spain \\ ${ }^{3}$ Department of Biomedical \& Clinical Sciences, BKH/Obstetrics \& Gynaecology, Faculty of Medicine and Health Sciences, \\ Linköping University, Linköping, Sweden
}

How to cite: Parrilla I, Martinez EA, Gil MA, Cuello C, Roca J, Rodriguez-Martinez H, Martinez CA. Boar seminal plasma: current insights on its potential role for assisted reproductive technologies in swine. Anim Reprod. 2020;17(3):e20200022. https://doi.org/10.1590/1984-3143-AR2020-0022

\begin{abstract}
Seminal plasma (SP) supports not only sperm function but also the ability of spermatozoa to withstand biotechnological procedures as artificial insemination, freezing or sex sorting. Moreover, evidence has been provided that SP contains identifiable molecules which can act as fertility biomarkers, and even improve the output of assisted reproductive technologies by acting as modulators of endometrial and embryonic changes of gene expression, thus affecting embryo development and fertility beyond the sperm horizon. In this overview, we discuss current knowledge of the composition of SP, mainly proteins and cytokines, and their influence on semen basic procedures, such as liquid storage or cryopreservation. The role of SP as modulator of endometrial and embryonic molecular changes that lead to successful pregnancy will also be discussed.
\end{abstract}

Keywords: protein, cytokine, sperm, embryo, pig.

\section{Introduction}

The OECD-FAO predicts a $15 \%$ increase in global meat production, including pig meat, for 2027 (FAO, 2018). Such increase largely depends of a successful reproductive management of the herds by correctly implementing the reproductive biotechnologies available today (Choudhary et al., 2016), such as artificial insemination (Al) or embryo transfer (ET) to ensure a sustained production of large litters. Therefore, it is mandatory to develop new strategies that help to reach such outputs, alongside higher economical and, potentially, environmental benefits by keeping the number of breeders at optimal levels, e.g. decreasing the number of low-effective breeders (Bromfield, 2016).

The early detection of boars with compromised fertility is then a logical priority for $\mathrm{Al}$ programs (Roca et al., 2015). However, it is generally accepted that conventional semen evaluation methods offer only a rough assessment of the real fertility potential of a boar (Dyck et al., 2011). In an attempt to overcome this drawback, special attention has been given to the study of the composition of seminal plasma (SP) as a potential source of biomarkers that

*Corresponding author: parrilla@um.es

Received: March 10, 2020. Accepted: April 14, 2020.

Financial support: Some of the studies presented in this review were supported by the Ministry of Economy and Competitiveness (Madrid, Spain)/the

European Regional Development Fund (AGL2015-69735-R; AGL2015-69738-R); the Ministry of Science, Innovation and Universities/the European Regional

Development Fund (RTI2018-093525-B-I00), Madrid, Spain; the European Union's Horizon 2020 research and innovation programme under the Marie

Sklodowska-Curie grant agreement (No 891663); the Seneca Foundation, Murcia, Spain (grant number 19892/GERM/15; 20780/PD/18) and the Research

Council FORMAS, Stockholm, Sweden (Projects 2017-00946 and 2019-00288).

Conflicts of interest: The authors have no conflict of interest to declare.

(c) (i) Copyright (c) The Author(s). This is an Open Access article distributed under the terms of the Creative Commons Attribution License, which permits unrestricted use, distribution, and reproduction in any medium, provided the original work is properly cited. 
could help to identify sub-fertile Al-boars that escape conventional semen screening yet providing sub-fertile semen (Pérez-Patiño et al., 2019). Sperm physiology and fertilizing ability are highly influenced by SP composition, which promotes sperm function and survival (Schjenken and Robertson, 2014). Moreover, the use of boar SP as an additive to optimize the quality of functional characteristics of biotechnologically treated spermatozoa has also been described (Parrilla et al., 2009; Caballero et al., 2012). Very recent reports of studies performed at a molecular level indicate that the SP effectively modulates the uterine environment in gilts and sows at different stages of the estrous cycle (pre-, peri-, post-ovulatory, and early pregnancy stages; Waberski et al., 2018; Alvarez-Rodriguez et al., 2019; Martinez et al., 2019c), potentially establishing best conditions for embryonic development and implantation. These findings are extremely relevant, especially in the field of reproductive technologies in pigs, since their implementation could result in important improvements in reproductive efficiency when using Al or ET largely impacting the production sector.

The present review summarizes current knowledge about boar SP, focusing mainly on those aspects related with the preservation of sperm function, as well as a source of potential biomarkers of boar fertility. In addition, the role of SP among the signaling mechanisms to help establish a successful pregnancy will also be discussed.

\section{Seminal plasma characteristics and composition}

SP is a complex fluid in which spermatozoa are sequentially suspended during the ejaculation process and it is composed of a mixture of secretions from the testis, epididymis, but mainly from the sexual accessory glands (Mann and Lutwak-Mann, 1981). In boar, the SP represents the major portion of the ejaculate volume (approximately 95\%) being physiologically emitted in fractions, which can be collected and analyzed separately; these fractions are different in terms of origin and composition (Rodriguez-Martinez et al., 2009).

The most relevant components of boar SP are listed in Table 1. Below, we will discuss the influence of some of these SP constituents on sperm function. The SP proteins and cytokines will be reviewed in separate sections due to their major role in regulating sperm function and fertility outcomes.

Table 1. Most relevant components of boar seminal plasma.

\begin{tabular}{|c|c|c|c|}
\hline Component & Source & Suggested functions & Reference \\
\hline \multicolumn{4}{|c|}{ Ions } \\
\hline $\mathrm{Na}$ & $\begin{array}{l}\text { Testes; Cauda Epididymis; } \\
\text { Vesicular Glands; } \\
\text { Bulbouretral Glands }\end{array}$ & $\begin{array}{l}\text { Osmotic balance; sperm } \\
\text { motility; sperm morphology; } \\
\text { sperm metabolism }\end{array}$ & $\begin{array}{l}\text { López-Rodriguez et al. } \\
\qquad(2013)\end{array}$ \\
\hline $\mathrm{Ca}$ & $\begin{array}{l}\text { Testes; Cauda Epididymis; } \\
\text { Vesicular Glands }\end{array}$ & $\begin{array}{l}\text { Acrosome reaction; sperm } \\
\text { motility }\end{array}$ & $\begin{array}{l}\text { López-Rodriguez et al. } \\
\text { (2013) }\end{array}$ \\
\hline $\mathrm{K}$ & $\begin{array}{c}\text { Testes; Cauda Epididymis; } \\
\text { Vesicular Glands; } \\
\text { Bulbouretral Glands }\end{array}$ & Sperm motility & $\begin{array}{l}\text { Juyena and Stelletta } \\
\text { (2012), Johnson et al. } \\
\text { (2000) }\end{array}$ \\
\hline Bicarbonate & Prostate; Vesicular Glands & $\begin{array}{l}\text { Sperm motility; induction of } \\
\text { plasma membrane } \\
\text { destabilization }\end{array}$ & $\begin{array}{c}\text { Rodriguez- } \\
\text { Martinez et al. (2009) }\end{array}$ \\
\hline $\mathrm{Mg}$ & $\begin{array}{l}\text { Cauda Epididymis; Vesicular } \\
\text { Glands; Bulbouretral Glands }\end{array}$ & $\begin{array}{l}\text { Enzymatic systems; sperm } \\
\text { motility } \\
\text { integrity of sperm membrane }\end{array}$ & $\begin{array}{l}\text { Juyena and Stelletta } \\
\text { (2012), López- } \\
\text { Rodriguez et al. (2013) }\end{array}$ \\
\hline Se & $\begin{array}{l}\text { Epididymis; Prostate; } \\
\text { Vesicular Glands }\end{array}$ & $\begin{array}{l}\text { Sperm motility; sperm } \\
\text { morphology; sperm viability } \\
\text { and integrity of DNA; } \\
\text { structural component of } \\
\text { glutathione peroxidase }\end{array}$ & $\begin{array}{c}\text { López-Rodriguez et al. } \\
\text { (2013), Pipan et al. } \\
\text { (2017), Barranco et al. } \\
\text { (2016), Qazi et al. } \\
\text { (2019) }\end{array}$ \\
\hline
\end{tabular}


Table 1. Continued...

\begin{tabular}{|c|c|c|c|}
\hline Component & Source & Suggested functions & Reference \\
\hline Zn & Vesicular Glands & $\begin{array}{c}\text { Mitochondrial function; } \\
\text { protection against oxidative } \\
\text { stress; antibacterial activity of } \\
\text { SP; stabilization of DNA } \\
\text { nucleoproteins; control of } \\
\text { energy for sperm motility; } \\
\text { in vivo fertility }\end{array}$ & $\begin{array}{c}\text { Boursnell et al. (1972) } \\
\text { Guthrie et al. (2008), } \\
\text { López-Rodriguez et al. } \\
\text { (2013) }\end{array}$ \\
\hline \multicolumn{4}{|c|}{ Enzymes } \\
\hline ALP & Epididymis & $\begin{array}{l}\text { spermatozoa quiescence } \\
\text { Modulation of fertilizing } \\
\text { capability acquisition }\end{array}$ & $\begin{array}{l}\text { López-Rodriguez et al. } \\
\text { (2013), Bucci et al. } \\
\text { (2014) }\end{array}$ \\
\hline AST & $\begin{array}{l}\text { Epididymis } \\
\text { Vesicular Glands }\end{array}$ & $\begin{array}{l}\text { Indicator of sperm cell } \\
\text { damage }\end{array}$ & $\begin{array}{l}\text { López-Rodriguez et al. } \\
\text { (2013), Ciereszko et al. } \\
\text { (1992) }\end{array}$ \\
\hline AP & $\begin{array}{l}\text { Epididymis } \\
\text { Vesicular Glands }\end{array}$ & $\begin{array}{c}\text { Sperm plasma membrane } \\
\text { integrity } \\
\text { Control of sperm metabolism }\end{array}$ & $\begin{array}{l}\text { Wysocki and Strzezek } \\
(2000)\end{array}$ \\
\hline GGT & & $\begin{array}{l}\text { Protective effect of sperm } \\
\text { against oxidative stress }\end{array}$ & $\begin{array}{l}\text { López-Rodriguez et al. } \\
\text { (2013) }\end{array}$ \\
\hline $\begin{array}{c}\text { LDH } \\
\text { (isoenzyme LDH 4) }\end{array}$ & Testes; Epididymis & $\begin{array}{c}\text { Necessary for energy } \\
\text { metabolism of sperm } \\
\text { Maintenance of sperm } \\
\text { motility } \\
\text { Involved in sperm } \\
\text { capacitation }\end{array}$ & $\begin{array}{l}\text { Sopkova et al. (2015), } \\
\text { Mann and } \\
\text { Lutwak-Mann (1981) }\end{array}$ \\
\hline SOD & $\begin{array}{l}\text { Epididymis; Vesicular Glands; } \\
\text { Prostate }\end{array}$ & $\begin{array}{l}\text { Sperm protection against } \\
\text { reactive oxygen species }\end{array}$ & Roca et al. (2005) \\
\hline PON-1 & Testes; Epididymis & $\begin{array}{l}\text { Prevent oxidation of } \\
\text { low-density lipoprotein } \\
\text { cholesterol }\end{array}$ & Barranco et al. (2015a) \\
\hline GPX-5 & $\begin{array}{l}\text { Testis; Epididymis } \\
\text { Vesicular Glands; Prostate; } \\
\text { Bulbourethral Glands }\end{array}$ & $\begin{array}{l}\text { Neutralizing } \mathrm{H}_{2} \mathrm{O}_{2} \\
\text { Sperm protection against } \\
\text { reactive oxygen species }\end{array}$ & Barranco et al. (2016) \\
\hline \multicolumn{4}{|c|}{ Energy Substrates } \\
\hline $\begin{array}{l}\text { Glucose, fructose, } \\
\text { sorbitol }\end{array}$ & Vesicular Glands & $\begin{array}{l}\text { Energy source and } \\
\text { modulators of sperm } \\
\text { function }\end{array}$ & Rodríguez-Gil (2013) \\
\hline \multicolumn{4}{|c|}{ Other relevant components } \\
\hline Citric Acid & $\begin{array}{l}\text { Cauda Epididymis; Vesicular } \\
\text { Glands }\end{array}$ & $\begin{array}{l}\mathrm{pH} \text { control in boar semen; } \\
\mathrm{Zn}, \mathrm{Mg} \text { and Ca chelator }\end{array}$ & $\begin{array}{l}\text { Setchell and Brooks } \\
\text { (1988), Kamp and } \\
\text { Lauterwein (1995) }\end{array}$ \\
\hline Inositol & Vesicular Glands & $\begin{array}{l}\text { Maintenance of osmotic } \\
\text { balance }\end{array}$ & $\begin{array}{l}\text { Mann and Lutwak- } \\
\text { Mann (1981), Setchell } \\
\text { and Brooks, } 1988\end{array}$ \\
\hline Phosphate & $\begin{array}{l}\text { Testes; Cauda Epididymis; } \\
\text { Vesicular glands; } \\
\text { Bulbouethral Glands }\end{array}$ & Sperm motility & $\begin{array}{c}\text { Setchell and Brooks } \\
\text { (1988), López- } \\
\text { Rodriguez et al. (2013) }\end{array}$ \\
\hline $\begin{array}{c}\text { Glycero- } \\
\text { phosphocholine }\end{array}$ & $\begin{array}{l}\text { Cauda Epididymis; Vesicular } \\
\text { Glands }\end{array}$ & $\begin{array}{l}\text { Reserve of substrate } \\
\text { Reduce sperm motility in-vitro } \\
\text { Regulation of osmotic } \\
\text { pressure }\end{array}$ & $\begin{array}{c}\text { Mann and } \\
\text { Lutwak-Mann (1981), } \\
\text { Cooper (1986) }\end{array}$ \\
\hline Ergothioneine & $\begin{array}{l}\text { Cauda Epididymis; Vesicular } \\
\text { Glands }\end{array}$ & $\begin{array}{c}\text { Prevention of lipid } \\
\text { peroxidation } \\
\text { Maintenance of intracellular } \\
\text { SH-groups in a physiologically } \\
\text { active } \\
\text { condition }\end{array}$ & $\begin{array}{l}\text { Mann and Leone } \\
\text { (1953), } \\
\text { Nikodemus et al. } \\
\text { (2011) }\end{array}$ \\
\hline Hypotaurine & Cauda Epididymis & $\begin{array}{l}\text { Osmoregulation and } \\
\text { reducing agent }\end{array}$ & Johnson et al. (1972) \\
\hline
\end{tabular}




\section{Ions}

Macroelements such as sodium, calcium, potassium, magnesium and chlorine greatly influence sperm functions (Hamamah and Gatti, 1998). In boar, sodium and chlorine are the most abundant ions and, among other functions, they influence metabolism and hence sperm motility and membrane stability, which can modify the morphology of spermatozoa (López-Rodriguez et al., 2013). Potassium, a metabolic inhibitor, decreases sperm metabolism and hence lowers sperm motility (Juyena and Stelletta, 2012; Johnson et al., 2000). Calcium, of utmost relevance for sperm motility variations, is pivotal when triggering the acrosome reaction (Juyena and Stelletta, 2012). Magnesium is involved in almost all enzymatic reactions, and thus related to sperm motility and sperm membrane preservation (Juyena and Stelletta, 2012; López-Rodriguez et al., 2013). Other ions present in boar SP, such as copper, selenium and zinc, also influence sperm quality (Pipan et al., 2017). Selenium is a component of glutathione peroxidase, an enzyme with antioxidant properties whose presence in the SP has been associated with sperm survival and in vivo fertility (Barranco et al., 2016). Moreover, recent studies have shown that selenium in the SP is related to sperm motility, morphology, and viability and the integrity of DNA (Pipan et al., 2017). Zinc is essential for chromatin intactness, preserves mitochondrial function and acts as a protective agent against oxidative stress (Guthrie et al., 2008) and contributes to the antibacterial activity of SP (Juyena and Stelletta, 2012). Finally, higher levels of other ions, including iron and copper, have been correlated with a higher number of functional sperm after storage (Pipan et al., 2017).

\section{Enzymes}

There are a wide variety of enzymes in the SP that have different functions. Very recently, it has been observed that more than $3 \%$ of the pig SP proteome are enzymes (Roca et al., 2020). Among them, there are several with antioxidant properties, whose main action is to reduce lipid peroxidation to protect spermatozoa from excessive levels of reactive oxygen species (ROS), particularly relevant in pigs due to the high sensitivity of their spermatozoa to oxidative stress (Radomil et al., 2011; Li et al., 2018). Superoxide dismutase (SOD), catalase (CAT), glutathione peroxidase (GPx), glutathione reductase, glutathione S-transferase, phospholipid hydroperoxide glutathione peroxidase, gamma-glutamyl transferase (GGT) and paraoxonase type 1 (PON-1) are among the antioxidant enzymes present in boar SP (López-Rodriguez et al., 2013; Koziorowska-Gilun et al., 2011; Barranco et al., 2015a, c, 2016).

Many of these enzymes have positive effects on the function of frozen-thawed (SOD; Roca et al., 2005) and refrigerated (PON-1 and GPx5; Barranco et al., 2016) spermatozoa, on the sperm concentration in the ejaculate and progressive motility (GGT; López-Rodriguez et al., 2013). Moreover, SOD, PON-1 and GPX-5 have been positively associated with the sperm response to cryopreservation, as they minimize oxidative stress associated with this procedure (Li et al., 2018).

Other enzymes present in boar SP are those related to preserving the stability of the sperm plasma membrane and sperm metabolic function. For instance, lactate dehydrogenase (LDH) and especially its isoenzyme LDH-C4 are important indicators of fertility, displaying higher concentrations among normospermic boars with high sperm motility (Sopkova et al., 2015). Aspartate amino transferase (AAT) activity in SP indicates sperm damage (Forejtek and Navratil, 1984) being negatively correlated to normal mophology, intact acrosomes and normal fertility (Juyena and Stelletta, 2012; López-Rodriguez et al., 2013). High activity of acid phosphatase has been correlated with sperm concentration, motility, and integrity of the acrosome membrane (Wysocki and Strzezek, 2000), while alkaline phosphatase activity might play a role in preventing premature capacitation and, therefore, preserving fertilizing ability (Bucci et al., 2014). 


\section{Energy substrates}

To maintain their functionality and especially to ensure adequate motility, boar spermatozoa require energy that is usually obtained from exogenous substrates present in SP. Monosaccharides, such as glucose and fructose, and polyols, such as sorbitol, are the main energy sources for sperm present in boar SP, and glycolysis the main pathway of glucose utilization, producing pyruvate/lactate (Mann and Lutwak-Mann, 1981; Setchell and Brooks, 1988; Marin et al., 2003). However, boar spermatozoa can, in the absence of monosaccharides, also use other substrates, such as glycerol, lactate, pyruvate and citrate (Rodríguez-Gil, 2013). It is worth noting that knowledge of energy regulation sperm mechanisms is fundamental to design strategies for adequate handling and storage conditions for best preservation of sperm quality.

There are many other constituents of SP that modulate sperm functions, and some details about them have been included in Table 1.

\section{Seminal plasma and semen technologies}

The addition of SP to boar sperm subjected to different biotechnological treatments, such as sperm sex sorting or cryopreservation, has been proposed as a strategy to reduce negative effects (Maxwell and Johnson, 1999; Parrilla et al., 2009). However, contradictory results have been described (Novak et al., 2010; Yeste et al., 2017), probably mainly attributed to variations in the protein composition of SP (Druart et al., 2013; Pérez-Patiño et al., 2016).

\section{Seminal plasma proteins}

Proteins are one of the most important components of boar SP, with concentrations ranging from 30 to $60 \mathrm{~g} / \mathrm{L}$ (Rodriguez-Martinez et al., 2009). Many SP proteins bind to the surface of spermatozoa to modulate their functional capacity (Caballero et al., 2012; Parrilla et al., 2019). These proteins also protect spermatozoa during their transit through the sow genital tract, contributing to the regulation of the temporal kinetics of ovulation and subsequent corpus luteum development and facilitating, in combination with other SP components, early pregnancy success (Waberski et al., 1997; Troedsson et al., 2005; Bromfield, 2016). A direct relationship between several SP proteins and fertility has been demonstrated in several species (Mogielnicka-Brzozowska and Kordan, 2011).

In boar, most SP proteins are spermadhesins (75-90\% of total SP protein content; Rodriguez-Martinez et al., 2009), a highly multifunctional family of glycoproteins classified according their ability to bind (AQN-1, AQN-3 and AWN) or not (PSP-I and PSP-II), heparin. Within a boar ejaculate, the relative protein concentrations are low in the pre-sperm fraction and the first portion of the sperm rich fraction (SRF) and increase in latter fractions of the ejaculate (Rodriguez-Martinez et al., 2011) (Figure 1). 


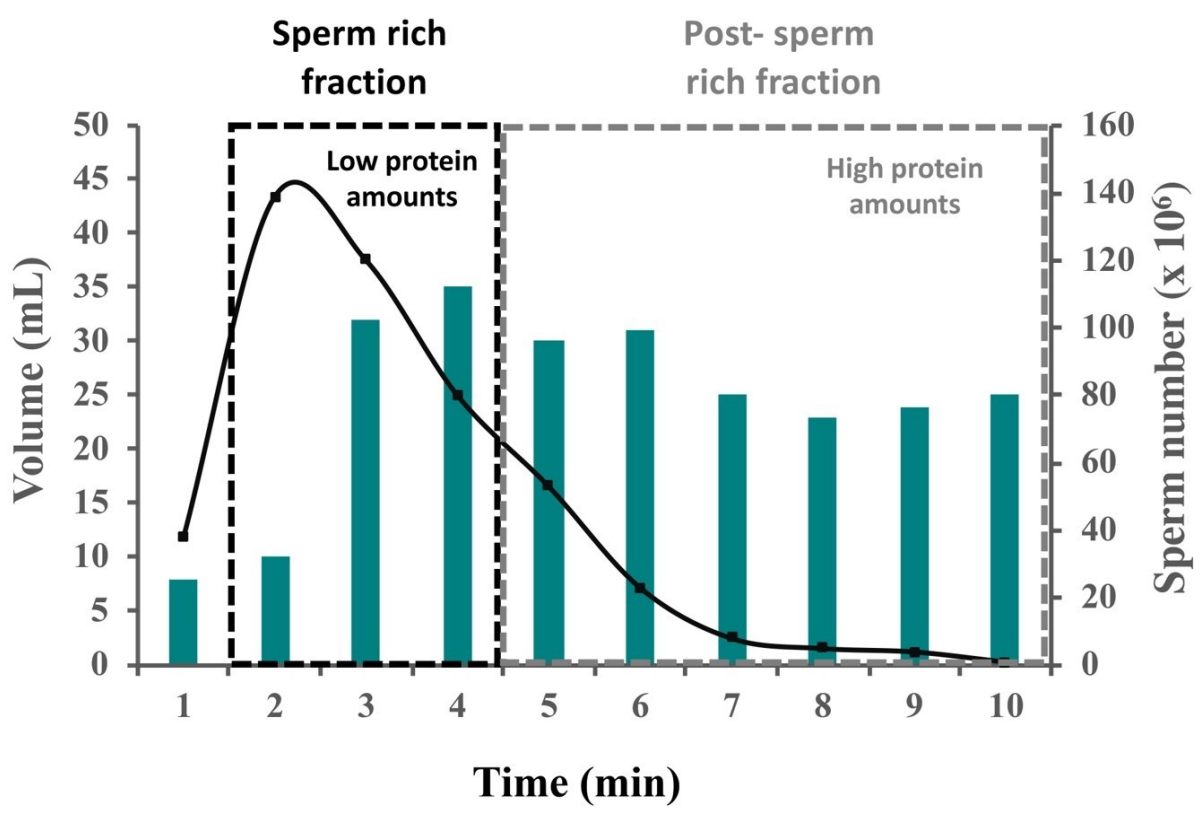

\section{Volume - Sperm number}

Figure 1. Boar ejaculate: Sperm concentration, ejaculate volume and relative amount of proteins in the consecutive portions of boar ejaculate namely, sperm rich fraction and post-sperm rich fraction. Modified from: Rodriguez-Martinez et al. (2009, 2011).

In vivo, several spermadhesins have been associated with sperm fertilization capability (Caballero et al., 2012). Moreover, numerous studies have focused on determining their potential use as biomarkers of male fertility and as additives for the improvement of biotechnologically treated spermatozoa (Dyck et al., 2011; Caballero et al., 2012; Vilagran et al., 2014). These studies have provided valuable information regarding their effects on sperm functional parameters and, more importantly, their potential relationship with boar sperm fertilization capability in vitro and in vivo (Garcia et al., 2007; Novak et al., 2010; Dyck et al., 2011; Caballero et al., 2012). However, although these findings were promising, they were focused on the identification of a single protein, while effective fertilization is the result of multiple interactions between different proteins. Therefore, more research is required to ensure the usefulness of these and other proteins as fertility markers.

To identify such proteins useable as fertility biomarkers, we performed proteomic analysis of the entire ejaculate and its fractions (first $10 \mathrm{~mL}$ of SRF, the rest of SRF and post-SRF) (Pérez-Patiño et al., 2016). We identified a total of 536 proteins in the entire ejaculate, 374 of which represented in the Sus scrofa taxonomy. Despite the high number of proteins identified, just 20 were directly related to reproductive processes, a striking finding when considering that the main effects of SP proteins are on sperm function and attainment of pregnancy (Caballero et al., 2012; Bromfield, 2016). Most likely, this finding was due to the incomplete association of the proteins identified with specific terms in the Gene Ontology knowledge base rather than to an actual deficiency among proteins related to reproductive functions (Pérez-Patiño et al., 2016). Despite this, the bioinformatic analysis showed that many of other identified proteins were related to important functions directly involved in reproductive processes, such as ion-and calcium-binding properties, glycosylation, immune responses and antioxidant activity, among others. In that study, we also showed quantitative rather than qualitative differences in protein SP-composition from the different ejaculate portions analyzed. There were no differences in protein levels between the first $10 \mathrm{~mL}$ of SRF and the rest of the SRF. In contrast, we found 34 proteins that were differentially expressed between the SRF and post-SRF. Sixteen of these proteins were represented in the Sus Scrofa taxonomy, and eight of them were overexpressed in SRF compared to their levels in the post-SRF. Some of the overexpressed proteins have been previously related to sperm capacitation, the acrosome reaction, zona pellucida binding, membrane stability and 
permeability (HEXB, GP2, ARSA, GLB1L3; Pérez-Patiño et al., 2016). Proteins overexpressed in the post-SRF were related to sperm maturation, sperm motility and bactericide activity. The remaining 18 differentially expressed proteins, which were not present in the Sus Scrofa taxonomy, were found to be involved in spermatogenesis, sperm maturation or mature sperm functionality in other species of mammals (Pérez-Patiño et al., 2016). These results seem to indicate that quantitative variations in SP-proteins are most likely responsible for the different effects of SP from different fractions on boar spermatozoa (Garcia et al., 2007; Saravia et al., 2009; Novak et al., 2010; Alkmin et al., 2014).

In a subsequent study, Pérez-Patiño, et al. (2019) attempted to increase the number of less abundant SP-proteins, very relevant for biological processes, that could be detected by including a prefractionation step by solid phase extraction (Brewis and Gadella, 2010). A total of 872 proteins were identified, 336 more than in our previous study (Pérez-Patiño et al., 2016). Of these, 37 proteins related to reproductive functions. Notably, among them were the low-molecular weight and highly abundant spermadhesins (PSP-I, PSP-II, AWN, AQN-1, and AQN-3), which, as mentioned above, exert important effects on boar sperm functions (Caballero et al., 2012), ensuring the maintenance of the proper immune environment in the uterus for embryonic development (Rodriguez-Martinez et al., 2011). More importantly, we detected proteins differentially expressed in SP samples from boars with different farrowing rates and litter sizes (data recorded from 10,526 sows; Pérez-Patiño et al., 2019). Eleven proteins were differentially expressed in boars with high- and low- farrowing rates (8 overexpressed and 3 underexpressed in boars with high farrowing rates). Among the overexpressed proteins, 4 proteins (furin, UBA1, SPAM-1, and AKR1B1) showed a direct implication in male reproductive success, such as sperm maturation, capacitation, motility, and fertilizing ability (Pérez-Patiño et al., 2019). We speculate that a higher expression of these proteins would contribute to successful fertilization, as reflected by the higher farrowing rates obtained when these boars were used for Al. Regarding the differentially expressed SP proteins in boars with larger and smaller litter sizes, we identified 4 other proteins; two of them (DSC-1 and (AT) overexpressed in those boars with larger litter sizes. The DSC-1 is involved in the proper functioning of spermatogenesis, while CAT is a well-known antioxidant enzyme, protecting against ROS (Awda et al., 2009). The PN-1 was one of the underexpressed SP proteins, which has been related to seminal vesicles dysfunction in humans when present in excess and with infertility when lacking (Murer et al., 2001). The other underexpressed protein was THBS1, whose presence in SP during Al alters maternal-conceptus communication in early pregnancy stages (Edwards et al., 2011). The low expression of these SP-proteins in boars with larger litter sizes suggests they could be used as potential fertility biomarkers.

\section{Seminal plasma cytokines}

Cytokines are a family of proteins of low molecular weight (between 5 and 20 kDa) mainly known for being involved in the immune response as regulatory factors (Jiang et al., 2016; Syriou et al., 2018). The role of cytokines in different reproductive events, including ovarian and testis functionality, embryonic development, endometrial immune responses and proper placental function and parturition, has been described by several authors (Robertson and Moldenhauer, 2014). In humans, cytokines are directly related to semen quality and functionality and play an important role in fertility regulation (Fraczek and Kurpisz, 2015). However, the potential influence of these cytokines on boar fertility profile is far from clear. To increase the understanding of SP cytokines in boars, we used a multiplex assay approach to identify and quantify different cytokines in SP from the SRF and post-SRF (Barranco et al., 2015b). Our results demonstrated that the SP of all analyzed boars contained a variety of measurable cytokines with pro- and anti-inflammatory activity. This fact suggests that, similar to that in humans and mice, that pig-SP could modulate uterine immune mechanisms to facilitate the transition from a primary anti-inflammatory response after Al to a more immunotolerant environment prior to embryo implantation (Robertson, 2005; Bromfield, 2014). More interestingly, our study found that cytokine concentrations varied among boars and ejaculated fractions, as they were more abundant in the post-SRF. Several authors have 
described the different tolerances of spermatozoa retrieved from the post-SRF to biotechnological procedures such as liquid storage or cryopreservation (Saravia et al., 2009; Alkmin et al., 2014). The possibility that SP cytokines, by interacting with spermatozoa, are partly responsible for these differences deserves to be thoroughly studied. In this line, we have shown how specific boar SP cytokines could modulate sperm changes at different levels during preservation (Barranco et al., 2019; Table 2).

Table 2. Predictive value of seminal plasma cytokines for sperm quality and functionality parameters in liquid-stored and cryopreserved boar semen samples.

\begin{tabular}{|c|c|c|c|c|c|c|c|}
\hline $\begin{array}{l}\text { Seminal } \\
\text { plasma } \\
\text { cytokine }\end{array}$ & Sperm sample & $\begin{array}{c}\text { Total } \\
\text { motility }\end{array}$ & $\begin{array}{c}\text { Progressive } \\
\text { motility }\end{array}$ & Viability & $\begin{array}{c}\mathrm{H}_{2} \mathrm{O}_{2} \\
\text { generation }\end{array}$ & $\begin{array}{c}\text { Total } \mathbf{O}_{2} \\
\text { generation }\end{array}$ & $\begin{array}{c}\text { Lipid } \\
\text { peroxidation }\end{array}$ \\
\hline \multirow{2}{*}{ TGF- $\beta 1$} & Liquid & & & & & & \\
\hline & Cryopreserved & - & - & & & & + \\
\hline \multirow{2}{*}{ TGF- $\beta 2$} & Liquid & - & - & & & & \\
\hline & Cryopreserved & & & & & & \\
\hline \multirow{2}{*}{ TGF- $\beta 1$} & Liquid & + & + & & + & & \\
\hline & Cryopreserved & & & & & & \\
\hline \multirow{2}{*}{ GM-CSF } & Liquid & & & & & & \\
\hline & Cryopreserved & & & & + & & \\
\hline \multirow{2}{*}{ IFN-y } & Liquid & & & & + & & \\
\hline & Cryopreserved & + & + & + & + & - & - \\
\hline \multirow{2}{*}{ IL-1a } & Liquid & & & & & & \\
\hline & Cryopreserved & & & + & - & & \\
\hline \multirow{2}{*}{ IL-1Ra } & Liquid & - & - & & & & \\
\hline & Cryopreserved & - & - & - & & & - \\
\hline \multirow{2}{*}{ IL-2 } & Liquid & & & & & & \\
\hline & Cryopreserved & - & & & & & \\
\hline \multirow{2}{*}{ IL-4 } & Liquid & - & - & & & & \\
\hline & Cryopreserved & & - & - & - & & \\
\hline \multirow{2}{*}{ IL-6 } & Liquid & & & & & & \\
\hline & Cryopreserved & & & & & + & \\
\hline \multirow{2}{*}{ IL-8 } & Liquid & + & + & & & & \\
\hline & Cryopreserved & - & - & - & & + & + \\
\hline \multirow{2}{*}{ IL-10 } & Liquid & + & & & & & \\
\hline & Cryopreserved & & & & & + & \\
\hline \multirow{2}{*}{ IL-12 } & Liquid & & - & & - & - & \\
\hline & Cryopreserved & & & & & & \\
\hline \multirow{2}{*}{ IL-18 } & Liquid & + & + & & & & \\
\hline & Cryopreserved & & & & & - & \\
\hline
\end{tabular}

+ /-: Positive and negative relationship. *Viable sperm showing lipid peroxidation. Modified from Barranco et al. (2019). TGF: Transforming Growth Factor; GM-CSF: Granulocyte-Macrophage Colony Stimulation Factor; IFN: Interferon; IL: Interleukyn.

\section{Seminal plasma and embryo technologies}

Currently, it is widely recognized that SP not only plays a key role as a nutrient and vehicle for spermatozoa but also exerts important functions on the tissues of the female genital tract, impacting subsequent events such as fertilization, implantation and pregnancy (Robertson, 2005, 2007). Numerous studies in human, rodents and domestic species indicate that the SP contains specific constituents with potential to induce modifications at the molecular, biochemical and cellular levels in the female genital tract (Robertson, 2005, 2010; Rodriguez-Martinez et al., 
2011). Thus, the infusion of SP prior to Al alters the expression of many genes related to maternal immunity in the reproductive tract of peri-ovulating sows (Waberski et al., 2018; Alvarez-Rodriguez et al., 2019). The SP promotes the release of factors related to the development of preimplantation embryos during attachment (Schjenken and Robertson, 2014). However, the most substantial information regarding the effects of SP on embryonic developmental competency is derived from studies in rodents. In these species, the infusion of SP during estrus supports not only embryo development but also implantation (Pang et al., 1979; Queen et al., 1981). In the absence of SP, the rates of fertilization and preimplantation embryo development are reduced, and postimplantation pregnancy losses are increased (Peitz and Olds Clarke, 1986; O et al., 1988). Furthermore, in these species, surrogate females are usually treated with SP infusions during estrus in embryo transfer (ET) programs to increase embryo survival and implantation rates post-ET (Watson et al., 1983; Carp et al., 1984; Bromfield et al., 2004). Overall, these findings indicate that the effects of very early signaling of the infusions of SP during estrus remain influential over time and affect later processes related to preimplantation embryo development and implantation, at least in rodents. Despite this evidence, studies of the molecular changes in the preimplantation porcine endometrium and embryos in response to SP, which would be of enormous importance for porcine ET technology, have been limited.

\section{Seminal plasma and the transcriptional pattern of the preimplantation endometrium}

Infusion of SP at the onset of estrus interacts with the endometrium and induces the modification of certain cytokines, such as granulocyte macrophage colony-stimulating factor (O'Leary et al., 2004), which is a promoter of the development and viability of mammalian preimplantation embryos (Sjoblom et al., 2002). Furthermore, these authors indicated that endometrial cytokine changes induced by SP infusions lasted for at least the first 9 days of pregnancy and were accompanied by an increase in embryo viability and changes in the kinetics of embryos, delaying their development.

We recently examined the effects of SP on the development and viability of porcine preimplantation embryos and the changes of the global transcriptome of the endometrium (Martinez et al., 2019c). In this study, post-weaning estrus sows received intrauterine infusions of SP or Beltsville Thawing Solution (BTS; Pursel and Johnson, 1975) 30 minutes before each insemination. Embryos and endometrium samples were removed during laparotomy 6 days after the infusions to morphologically evaluate the embryos and analyze the endometrial transcriptome, at Day 6 of the cycle when embryo collection and transfer are usually performed in pig ET programs. The endometrial morphology was affected by the infusion of SP, showing accentuated inflammatory changes compared to endometria from the BTS group. The changes included congestion, leukocyte margination, edema, hemorrhages and infiltrates of immune cells in the mucosal connective tissue and the uterine glands. These results support previous findings in humans and pigs, indicating that the effects of SP infusions during estrus can be observed throughout the preimplantation period in pigs (Aumüller and Riva, 1992; Maegawa et al., 2002; O'Leary et al., 2004).

On the other hand, all studies of the endometrial transcriptome during the porcine peri-implantation period have revealed alterations in the expression of genes associated with the maternal immune response (Samborski et al., 2013; Kiewisz et al., 2014; Lin et al., 2015). However, endometrial receptivity during the preimplantation period, which is greatly influenced by alterations in cytokines and other compounds secreted into the uterine fluid (Morris and Diskin, 2008; Bazer and Johnson, 2014), is also critical for the development of embryos and the appropriate progression of pregnancy. Surprisingly, we identified more than 1,600 expressed transcripts with differential abundance in the endometria of the SP and BTS groups. The endometria from SP sows showed an overrepresentation of genes associated with immune pathways, including genes such as DLG1, FAS, LGALS1, STAT5A and IRF1. Regulatory T (Treg) cells, which are a subset of CD4+ T cells, are efficient immune suppressors that play important roles in the cell-mediated immune response (Rudensky, 2011) and, therefore, are key to preventing immune rejection of the developing hemi-allogeneic embryo/fetus (Shevach, 
2002; Aluvihare et al., 2004). Treg cells play a pivotal role in the progression of pregnancy by suppressing the proliferation of T and B cells (Shevach, 2002; Lim et al., 2006), inhibiting the maturation and activation of dendritic cells (DCs) and macrophages (Taams and Akbar, 2005) and preventing the cytotoxicity of natural killer cells (Ghiringhelli et al., 2005). In this regard, SP-treated sows showed evidence of the overactivation of the transforming growth factor- $\beta$ (TGF-ß) signaling pathway, which is a pathway that supports the proliferation of Treg cells by regulating DC function (Ghiringhelli et al., 2005). Altogether, these findings indicated that SP infusions prior to $\mathrm{Al}$ increase the development of Treg cells and control the immune response of the female in response to the presence of hemi-allogeneic embryos as early as Day 6 of pregnancy. The implications of these findings could help us reduce the immune response of subrogate females to allogeneic transferred embryos, thus decreasing the high embryonic death characteristic of current ET.

It is known that the development of embryos during the preimplantation period is severely influenced by cytokines present in uterine fluids, which either promote or limit embryonic development (Hardy and Spanos, 2002; Sjoblom et al., 2005; O'Neill, 2008). In our study, numerous genes associated with the cytokine-cytokine receptor signaling pathway were either over- or under-expressed in uterine samples exposed to SP. For example, the CD27 and CD70 genes were downregulated. The proteins encoded by these genes are costimulators of an embryotoxic cytokine (TNF-a) that increases apoptosis and inhibits embryonic development and implantation (Chaouat et al., 1990).

The development of embryos from the zygote stage to the implantation stage is controlled by many hormones, which adjust the maternal physiology to support pregnancy (Waclawik et al., 2017). Pre-Al SP infusions induce hormonal changes in the uterine environment via the overexpression of genes related to steroid and estrogen signaling.

SP-infusions also noticeably altered other pathways implicated in embryonic development and implantation. For instance, we found upregulation of the PI3K/AKT, MAPK/ERK and Wnt signaling pathways, which seem to play a fundamental role in regulating not only cell functions, including proliferation, differentiation, mitogenesis, and cell survival (Songyang et al., 1997; Nayeem et al., 2016), but also sperm functions, such as the capacitation process (Almog and Naor, 2010), and embryonic development and cytoskeletal remodeling of preimplantation trophoblast cells (Qiu et al., 2004; Bazer et al., 2010). Moreover, deficiencies in MAPK/ERK proteins result in embryonic loss by altering the trophoblast proliferation process (Saba-El-Leil et al., 2003; Jeong et al., 2013).

SP infusions induced the overexpression of many other genes of interest in the endometrium, such as HOXB4, GRHL2, RAB14, MGAT1 and ACVR2A. All these genes have been associated with normal early embryonic development (Scott and Carroll, 1987; Blitek et al., 2011; Grasa et al., 2012; Petrof et al., 2014; Yong et al., 2018; Ming et al., 2018). Although the adhesion of embryos to the endometrium occurs on Days 12-16 of pregnancy, SP infusions at estrus altered, on Day 6 of pregnancy, genes that are particularly involved in cell adhesion pathways that can be responsible for increasing implantations success. Altogether, these results show that SP infusions during estrus affect the transcriptional expression profile of porcine endometrium during early pregnancy.

\section{Seminal plasma and preimplantation embryos}

SP-infusions during estrus result in a higher percentage of advanced stage embryos as early as 6 days post-Al compared to that in controls (BTS infusions) without affecting neither fertilization rate nor embryo viability (Martinez et al., 2019c). These changes in embryonic development might be associated with variations in ovulation time in response to SP treatment. The SP alters the endocrine-immune-cytokine system in preovulatory follicles (Einer-Jensen and Hunter, 2005; O'Leary et al., 2006) by decreasing the LH peak ovulation interval and, therefore, hastening the time of ovulation (Schuberth et al., 2008). Accordingly, embryos collected from sows treated with SP should have reached a more advanced developmental stage than those collected from non-treated sows. However, SP could also 
directly affect embryo development because, as discussed above, the effects of SP extend beyond the time immediately after exposure. Our findings, which indicated that SP did not affect embryo viability but advanced the developmental stage of the embryos, are in contrast with previous results reported by O'Leary and coworkers (O'Leary et al., 2004), who observed that SP increased embryo viability and delayed embryonic development at Day 9 of pregnancy. The discrepancies between these studies could be attributed to differences in the methodology used for evaluating embryonic development. While we used the classical morphological evaluation method to determine the stage of the embryos, the authors of the other study evaluated the developmental stage by measuring the diameter of hatched Day 9 blastocysts, when a number of them collapsed or presented irregular morphology (Sun et al., 2015). In addition, similar to previous studies on ET (Martinez et al., 2014, 2015, 2019a, b, d), we had a high embryo viability rate on day 6 of pregnancy $(>90 \%)$, which complicated the detection of significant differences between the SP and control groups.

Interestingly, recent studies from our laboratory indicate that SP infusions during estrus also modify the gene expression of Day 6 blastocysts. Transcriptome analysis of these embryos revealed 210 annotated transcripts that were differentially expressed in blastocysts derived from SP sows relative to those found in blastocysts derived from BTS sows (93 upregulated and 117 downregulated). Most of these genes were associated with biological, cellular, metabolic and developmental processes. When we analyzed the differentially expressed genes to identify the significant KEGG pathways, a total of 3 and 13 pathways were enriched in the down- and upregulated gene lists, respectively. Three pathways involved in mineral absorption, regulation of lipolysis in adipocytes and p53 signaling were enriched in the downregulated gene list and included genes, such as MT-2B, PTGS1, ADORA1, CDK2 and SERPINE1, with no evident association with embryonic development or implantation. The pathways enriched among the upregulated genes included pathways related to signal transduction (apelin signaling, FoxO signaling and mTOR signaling), cellular processes (cell cycle, p53 signaling, cellular senescence, adherents junction and signaling pathways regulating pluripotency of stem cells), and the endocrine system (insulin signaling, progesterone-mediated oocyte maturation and relaxin signaling). These pathways contain genes with potential roles in embryonic development, implantation, or progression of pregnancy, such as MAPK1, SMAD2, CDK1, APOA-I, PRKAA1 and RICTOR. Our results demonstrate that SP infusions upregulated the expression of these genes, which may favor embryonic developmental capability.

The MAPK1 gene encodes a member of the MAP kinase family that is involved in several cellular processes, such as proliferation, differentiation, transcription regulation and development. Studies in several species have shown that deficits in MAPK proteins cause early embryonic mortality due to the lack of signal transduction for proliferation and invasion of trophoblasts (Saba-El-Leil et al., 2003; Jeong et al., 2013). It has been shown in mice that MAPK1 is essential not only for embryonic development but also for placental development (Hatano et al., 2003) and development of the mesoderm (Yao et al, 2003).

The protein encoded by the SMAD2 gene mediates the TGF- $ß$ signaling pathway, which is an essential pathway controlling the initial developmental steps, such as epiblast development and patterning of the three germ layers (Liu et al., 2016). In addition, as mentioned above, the TGF-ß superfamily supports the proliferation of Treg cells, which are crucial for preventing immune rejection and thus tolerating the fetal allograft.

Another upregulated gene in SP blastocysts was CDK1, a gene indispensable not only for the mitotic cell cycle (Santamaría et al., 2007; Gavet and Pines, 2010) but also for the resumption of meiosis in oocytes (Adhikari et al., 2012), which supports the conclusion that CDK1 may contribute to embryo viability.

Other interesting genes were ApoA1, PRKAA1 and RICTOR. The ApoA1 gene encodes apolipoprotein A-I, a principal constituent of high-density lipoprotein, which has been shown to be upregulated in the murine endometrium during implantation (Gou et al., 2015). Moreover, it has been suggested that ApoA1 plays important roles in embryo implantation by inhibiting lipid peroxidation (Jia et al., 2016). Furthermore, a role for ApoA1 in early embryonic development has also been suggested, as this protein is produced by human preimplantation embryos, and increased ApoA1 levels are present in spent culture media containing blastocysts 
of high morphologic grade (Mains et al., 2011). Sensor systems for cellular metabolism and energy are essential during early embryonic development (McBride et al., 2009). The protein encoded by the PRKAA1 gene is the catalytic subunit of AMPK, which is a cellular energy metabolism sensor conserved in all mammalian cells. The metabolic sensor PRKAA1 seems to be important for embryonic development in sustaining cell polarity and advancing the cell cycle (Lee et al., 2007; Jansen et al., 2009). Finally, another upregulated gene that plays an important role in embryonic growth and development is RICTOR, a protein-encoding gene essential for the development of both embryonic and extraembryonic tissues, as its deficiency causes embryonic lethality in mice (Shiota et al., 2006).

\section{Final comments}

Achieving a successful pregnancy is the main goal of all reproductive biotechnologies. Boar SP has been demonstrated to be a determinant factor for basic sperm function. Moreover, boar SP acts as a protective factor for spermatozoa in its transit through the uterus and, more importantly, as a factor that prepares the uterine environment to receive the embryo, promoting its proper development and implantation.

Therefore, broadening the knowledge of the molecular mechanisms by which SP exerts its effects at the sperm, embryo and uterine levels is prerequisite for optimal design of adequate protocols that allow improved fertility results for procedures such as Al, cryopreservation and/or embryo transfer.

Currently, due to the use of 'omics techniques, the identification of reliable biomarkers to determine sperm function and fertility seems to be more likely in the near future. The economic impact of an increase in farrowing rates but particularly in live litter size that could result from selecting boars according to the expression of certain proteins, would have a great impact on pig productivity. Similarly, these potential biomarkers could be used as tools for improving current sperm preservation procedures. Future studies based on the recent and continuous advances in 'omics techniques will contribute to the identification of reliable biomarkers that can be used as fertility indicators and additives to improve the yields derived from the application of different assisted reproductive technologies in pigs.

Regarding embryo technologies, the possibilities of an increase in the productive and reproductive parameters derived from ET procedures, by applying strategies based in molecular indicators, would hugely contribute to its broad implementation. This would, in fact, accelerate genetic improvement and improve animal welfare. A greater knowledge of the impact of the different components of SP on the creation of a favorable uterine environment for pregnancy establishment is critical to improve the performance of embryonic technologies in pigs. In this review, we showed that SP infusions during estrus affected the transcriptional expression profile of the endometrium and preimplantation embryos during early pregnancy, by positively influencing the expression of genes and pathways associated with embryonic early development and facilitating achievement of the state of tolerance by the maternal immune system. Obviously, potential effects of SP infusions on the outcomes of ET programs need to be further explored.

\section{Acknowledgements}

The authors are grateful to the staff of Agropor SA (Murcia, Spain), and Porcisan (Murcia, Spain) for the excellent management of the animals in some of the studies reported here. AIM Ibérica (Murcia, Spain) is also grateful for supplying the boar ejaculates used in these studies.

\section{References}

Adhikari D, Zheng W, Shen Y, Gorre N, Ning Y, Halet G, Kaldis P, Liu K. Cdk1, but not Cdk2, is the sole Cdk that is essential and sufficient to drive resumption of meiosis in mouse oocytes. Hum Mol Genet. 2012;21(11):2476-84. http://dx.doi.org/10.1093/hmg/dds061. PMid:22367880. 
Alkmin DV, Pérez-Patiño C, Barranco I, Parrilla I, Vazquez JM, Martinez EA, Rodriguez-Martinez H, Roca J. Boar sperm cryosurvival is better after exposure to seminal plasma from selected fractions than to those from entire ejaculate. Cryobiology. 2014;69(2):203-10. http://dx.doi.org/10.1016/j.cryobiol.2014.07.004. PMid:25037026.

Almog T, Naor Z. The role of Mitogen Activated Protein Kinase (MAPK) in sperm functions. Mol Cell Endocrinol. 2010;314(2):239-43. http://dx.doi.org/10.1016/j.mce.2009.05.009. PMid:19467295.

Aluvihare VR, Kallikourdis M, Betz AG. Regulatory T cells mediate maternal tolerance to the fetus. Nat Immunol. 2004;5(3):266-71. http://dx.doi.org/10.1038/ni1037. PMid:14758358.

Alvarez-Rodriguez M, Atikuzzaman M, Venhoranta H, Wright D, Rodriguez-Martinez H. Expression of immune regulatory genes in the porcine internal genital tract is differentially triggered by spermatozoa and seminal plasma. Int J Mol Sci. 2019;20(3):1-20. http://dx.doi.org/10.3390/ijms20030513. PMid:30691059.

Aumüller G, Riva A. Morphology and functions of the human seminal vesicle. Andrologia. 1992;24(4):18396. http://dx.doi.org/10.1111/j.1439-0272.1992.tb02636.x. PMid:1642333.

Awda BJ, Mackenzie-Bell M, Buhr MM. Reactive oxygen species and boar sperm function. Biol Reprod. 2009;81(3):553-61. http://dx.doi.org/10.1095/biolreprod.109.076471. PMid:19357363.

Barranco I, Padilla L, Pérez-Patiño C, Vazquez JM, Martinez EA, Rodriguez-Martinez EA, Roca J, Parrilla I. Seminal plasma cytokines are predictive of the outcome of boar sperm preservation. Front Vet Sci. 2019;6:436. http://dx.doi.org/10.3389/fvets.2019.00436. PMid:31867346.

Barranco I, Roca J, Tvarijonaviciute A, Rubér M, Vicente-Carrillo A, Atikuzzaman M, Cerón JJ, Martínez EA, Rodríguez-Martínez $\mathrm{H}$. Measurement of activity and concentration of paraoxonase 1 (PON-1) in seminal plasma and identification of PON-2 in the sperm of boar ejaculates. Mol Reprod Dev. 2015a;82(1):58-65. http://dx.doi.org/10.1002/mrd.22444. PMid:25487823.

Barranco I, Rubér M, Pérez-Patiño C, Atikuzzaman M, Martinez EA, Roca J, Rodriguez-Martinez H. The seminal plasma of the boar is rich in cytokines, with significant individual and intra-ejaculate variation. Am J Reprod Immunol. 2015b;74(6):523-32. http://dx.doi.org/10.1111/aji.12432. PMid:26412440.

Barranco I, Tvarijonaviciute A, Pérez-Patiño C, Alkmin DV, Cerón JJ, Martínez EA, Rodríguez-Martínez H, Roca J. The activity of paraoxonase type $1(\mathrm{PON}-1)$ in boar seminal plasma and its relationship with sperm quality, functionality, and in vivo fertility. Andrology. 2015c;3(2):315-20. http://dx.doi.org/10.1111/andr.309. PMid:25598515.

Barranco I, Tvarijonaviciute A, Pérez-Patiño C, Vicente-Carrillo A, Parrilla I, Ceron JJ, Martinez EA, Rodriguez-Martinez $\mathrm{H}$, Roca J. Glutathione peroxidase 5 is expressed by the entire pig male genital tract and once in the seminal plasma contributes to sperm survival and in vivo fertility. PLoS One. 2016;11(9):e0162958. http://dx.doi.org/10.1371/journal.pone.0162958. PMid:27627110.

Bazer FW, Johnson GA. Pig blastocyst-uterine interactions. Differentiation. 2014;87(1-2):52-65. http://dx.doi.org/10.1016/j.diff.2013.11.005. PMid:24388881.

Bazer FW, Wu G, Spencer TE, Johnson GA, Burghardt RC, Bayless K. Novel pathways for implantation and establishment and maintenance of pregnancy in mammals. Mol Hum Reprod. 2010;16(3):135-52. http://dx.doi.org/10.1093/molehr/gap095. PMid:19880575.

Blitek A, Morawska E, Kiewisz J, Ziecik AJ. Effect of conceptus secretions on HOXA10 and PTGS2 gene expression, and PGE2 release in co-cultured luminal epithelial and stromal cells of the porcine endometrium at the time of early implantation. Theriogenology. 2011;76(5):954-66. http://dx.doi.org/10.1016/j.theriogenology.2011.05.002. PMid:21705055.

Boursnell JC, Baronos S, Briggs PA, Butler EJ. The concentration of Zinc in boar seminal plasma and vesicular secretion in relation to those of nitrgenous substances, citrate, galactose and fructose. J Reprod Fertil. 1972;29(2):215-27. http://dx.doi.org/10.1530/jrf.0.0290215. PMid:5023698.

Brewis IA, Gadella BM. Sperm surface proteomics: from protein list to biological function. Mol Hum Reprod. 2010;16(2):68-79. http://dx.doi.org/10.1093/molehr/gap077. PMid:19717474.

Bromfield JJ, Roberts CT, Robertson SA. Seminal plasma programs uterine receptivity and pregnancy outcome. In: Proceedings of the 37th Annual Meeting of the Society for the Study of Reproduction; 2004 Aug 1-4; Vancouver, British Columbia, Canada. Madison: Society for the Study of Reproduction; 2004.

Bromfield JJ. Seminal fluid and reproduction: much more than previously thought. J Assist Reprod Genet. 2014;31(6):627-36. http://dx.doi.org/10.1007/s10815-014-0243-y. PMid:24830788. 
Bromfield Jj. A role for seminal plasma in modulating pregnancy outcomes in domestic species. Reproduction. 2016;152(6):R223-32. http://dx.doi.org/10.1530/REP-16-0313. PMid:27601714.

Bucci D, Isani G, Giaretta E, Spinaci M, Tamanini C, Ferlizza E, Galeati G. Alkaline phosphatase in boar sperm function. Andrology. 2014;2(1):100-6. http://dx.doi.org/10.1111/j.2047-2927.2013.00159.x. PMid:24249651.

Caballero I, Parrilla I, Almiñana C, del Olmo D, Roca J, Martinez EA, Vázquez JM. Seminal plasma proteins as modulators of the sperm function and their application in sperm biotechnologies. Reprod Domest Anim. 2012;47(Suppl 3):12-21. http://dx.doi.org/10.1111/j.1439-0531.2012.02028.x. PMid:22681294.

Carp HJ, Serr DM, Mashiach S, Nebel L. Influence of insemination on the implantation of transferred rat blastocysts. Gynecol Obstet Invest. 1984;18(4):194-8. http://dx.doi.org/10.1159/000299080. PMid:6510779.

Chaouat G, Menu E, Clark DA, Dy M, Minkowski M, Wegmann TG. Control of fetal survival in CBA x DBA/2 mice by lymphokine therapy. J Reprod Fertil. 1990;89(2):447-58. http://dx.doi.org/10.1530/jrf.0.0890447. PMid:2119428.

Choudhary KK, Kavya KM, Jerome A, Sharma RK. Advances in reproductive biotechnologies. Vet World. 2016;9(4):388-95. http://dx.doi.org/10.14202/vetworld.2016.388-395. PMid:27182135.

Ciereszko A, Glogowski J, Strzezek J, Demianowicz W. Low stability of aspartate aminotransferase activity in boar semen. Theriogenology. 1992;37(6):1269-81. http://dx.doi.org/10.1016/0093-691X(92)90182Q.

Cooper TG. Function of the epididymis and its secretory products. In: Cooper TG, editor. The epididymis, sperm maturation and fertilisation. Berlin: Springer-Verlag; 1986. p. 174-272. http://dx.doi.org/10.1007/978-3-642-71471-9_12.

Druart X, Rickard JP, Mactier S, Kohnke PL, Kershaw-Young CM, Bathgate R, Gibb Z, Crossett B, Tsikis G, Labas V, Harichaux G, Grupen CG, de Graaf SP. Proteomic characterization and cross species comparison of mammalian seminal plasma. J Proteomics. 2013;91:13-22. http://dx.doi.org/10.1016/j.jprot.2013.05.029. PMid:23748023.

Dyck MK, Foxcroft GR, Novak S, Ruiz-Sanchez A, Patterson J, Dixon WT. Biological markers of boar fertility. Reprod Domest Anim. 2011;46(Suppl 2):55-8. http://dx.doi.org/10.1111/j.14390531.2011.01837.x. PMid:21884279.

Edwards AK, van den Heuvel MJ, Wessels JM, Lamarre J, Croy BA, Tayade C. Expression of angiogenic basic fibroblast growth factor, platelet derived growth factor, thrombospondin-1 and their receptors at the porcine maternal-fetal interface. Reprod Biol Endocrinol. 2011;9(1):5. http://dx.doi.org/10.1186/1477-7827-9-5. PMid:21241502.

Einer-Jensen N, Hunter RHF. Counter-current transfer in reproductive biology. Reproduction. 2005;129(1):9-18. http://dx.doi.org/10.1530/rep.1.00278. PMid:15615894.

Food and Agriculture Organization of the United Nations - FAO, Organisation for Economic Co-operation and Development - OECD. Agricultural outlook 2018-2027 [Internet]. Rome: OECD-FAO; 2018 [cited 2020 Mar 10]. Available from: http://www.fao.org/3/i9166e/i9166e_Chapter1.pdf

Forejtek P, Návratil S. Relation between aspartate aminotrasnferase (AST) activity in the seminal fluid and indicators of boar ejaculate quality. Vet Med. 1984;29(4):217-22. PMid:6426132.

Fraczek M, Kurpisz M. Cytokines in the male reproductive tract and their role in infertility disorders. J Reprod Immunol. 2015;108:98-104. http://dx.doi.org/10.1016/j.jri.2015.02.001. PMid:25796532.

García EM, Vazquez JM, Parrilla I, Calvete JJ, Sanz L, Caballero I, Roca J, Vazquez JL, Martinez EA. Improving the fertilizing ability of sex sorted boar spermatozoa. Theriogenology. 2007;68(5):771-8. http://dx.doi.org/10.1016/j.theriogenology.2007.06.006. PMid:17662382.

Gavet O, Pines J. Progressive activation of CyclinB1-Cdk1 coordinates entry to mitosis. Dev Cell. 2010;18(4):533-43. http://dx.doi.org/10.1016/j.devcel.2010.02.013. PMid:20412769.

Ghiringhelli F, Ménard C, Terme M, Flament C, Taieb J, Chaput N, Puig PE, Novault S, Escudier B, Vivier E, Lecesne A, Robert C, Blay J-Y, Bernard J, Caillat-Zucman S, Freitas A, Tursz T, Wagner-Ballon O, Capron C, Vainchencker W, Martin F, Zitvogel L. CD4 + CD25 + regulatory T cells inhibit natural killer cell functions in a transforming growth factor- $\beta$-dependent manner. J Exp Med. 2005;202(8):1075-85. http://dx.doi.org/10.1084/jem.20051511. PMid:16230475.

Gou J, Jia J, Zhao X, Yi T, Li Z. Identification of stathmin 1 during peri-implantation period in mouse endometrium by a proteomics-based analysis. Biochem Biophys Res Commun. 2015;461(2):211-6. http://dx.doi.org/10.1016/j.bbrc.2015.02.171. PMid:25866183. 
Grasa P, Kaune H, Williams SA. Embryos generated from oocytes lacking complex N- and O-glycans have compromised development and implantation. Reproduction. 2012;144(4):455-65. http://dx.doi.org/10.1530/REP-12-0084. PMid:22919046.

Guthrie HD, Welch GR, Long JA. Mitochondrial function and reactive oxygen species action in relation to boar motility. Theriogenology. 2008;70(8):1209-15. http://dx.doi.org/10.1016/j.theriogenology.2008.06.017. PMid:18667230.

Hamamah S, Gatti JL. Role of the ionic environment and internal pH on sperm activity. Hum Reprod. 1998;13(Suppl 4):20-30. http://dx.doi.org/10.1093/humrep/13.suppl_4.20. PMid:10091055.

Hardy K, Spanos S. Growth factor expression and function in the human and mouse preimplantation embryo. J Endocrinol. 2002;172(2):221-36. http://dx.doi.org/10.1677/joe.0.1720221. PMid:11834440.

Hatano N, Mori Y, Oh-hora M, Kosugi A, Fujikawa T, Nakai N, Niwa H, Miyazaki J, Hamaoka T, Ogata M. Essential role for ERK2 mitogen- activated protein kinase in placental development. Genes Cells. 2003;8(11):847-56. http://dx.doi.org/10.1046/j.1365-2443.2003.00680.x. PMid:14622137.

Jansen M, Ten Klooster JP, Offerhaus GJ, Clevers H. LKB1 and AMPK family signaling: the intimate link between cell polarity and energy metabolism. Physiol Rev. 2009;89(3):777-98. http://dx.doi.org/10.1152/physrev.00026.2008. PMid:19584313.

Jeong W, Kim J, Bazer FW, Song G. Epidermal growth factor stimulates proliferation and migration of porcine trophectoderm cells through protooncogenic protein kinase 1 and extracellular-signalregulated kinases 1/2 mitogen-activated protein kinase signal transduction cascades during early pregnancy. Mol Cell Endocrinol. 2013;381(1-2):302-11. http://dx.doi.org/10.1016/j.mce.2013.08.024. PMid:24012778.

Jia J, Gou J, Zhao X, Yi T, Li Z. Apolipoprotein A1 and heterogeneous nuclear ribonucleoprotein E1 implicated in the regulation of embryo implantation by inhibiting lipid peroxidation. Reprod Biomed Online. 2016;33(5):635-45. http://dx.doi.org/10.1016/j.rbmo.2016.07.011. PMid:27567428.

Jiang L, Zheng T, Huang J, Mo J, Zhou H, Liu M, Gao X, Yu B. Association of semen cytokines with reactive oxygen species and histone transition abnormalities. J Assist Reprod Genet. 2016;33(9):1239-46. http://dx.doi.org/10.1007/s10815-016-0756-7. PMid:27364628.

Johnson LA, Pursel VG, Gerrits RJ, Thomas CH. Free amino acid composition of porcine seminal, epididymal and seminal vesicle fluids. J Anim Sci. 1972;34(3):430-4. http://dx.doi.org/10.2527/jas1972.343430x. PMid:5010631.

Johnson LA, Weitze KF, Fiser P, Maxwell WM. Storage of boar semen. Anim Reprod Sci. 2000;62(1-3):14372. http://dx.doi.org/10.1016/S0378-4320(00)00157-3. PMid:10924823.

Juyena NS, Stelletta C. Seminal plasma: an essential attribute to spermatozoa. J Androl. 2012;33(4):53651. http://dx.doi.org/10.2164/jandrol.110.012583. PMid:22016346.

Kamp G, Lauterwein J. Multinuclear magnetic resonance studies of boar seminal plasma. Biochim Biophys Acta. 1995;1243(1):101-9. http://dx.doi.org/10.1016/0304-4165(94)00117-g. PMid:7827097.

Kiewisz J, Krawczynski K, Lisowski P, Blitek A, Zwierzchowski L, Ziecik AJ, Kaczmarek MM. Global gene expression profiling of porcine endometria on days 12 and 16 of the estrous cycle and pregnancy. Theriogenology. 2014;82(6):897-909. http://dx.doi.org/10.1016/j.theriogenology.2014.07.009. PMid:25123632.

Koziorowska-Gilun M, Koziorowski M, Fraser L, Strzeżek J. Antioxidant defence system of boar cauda epididymidal spermatozoa and reproductive tract fluids. Reprod Domest Anim. 2011;46(3):527-33. http://dx.doi.org/10.1111/j.1439-0531.2010.01701.x. PMid:20880161.

Lee JH, Koh H, Kim M, Kim Y, Lee SY, Karess RE, Lee SH, Shong M, Kim JM, Kim J, Chung J. Energydependent regulation of cell structure by AMP-activated protein kinase. Nature. 2007;447(7147):1017-20. http://dx.doi.org/10.1038/nature05828. PMid:17486097.

Li J, Barranco I, Tvarijonaviciute A, Molina FM, Martinez EA, Rodriguez-Martinez H, Parrilla I, Roca J. Seminal plasma antioxidants are directly involved in boar sperm cryotolerance. Theriogenology. 2018;107:27-35. http://dx.doi.org/10.1016/j.theriogenology.2017.10.035. PMid:29128698.

Lim B, Sutherland RM, Zhan Y, Deliyannis G, Brown LE, Lew AM. Targeting CD45RB alters T cell migration and delays viral clearance. Int Immunol. 2006;18(2):291-300. http://dx.doi.org/10.1093/intimm/dxh367. PMid:16361310.

Lin $\mathrm{H}$, Wang H, Wang Y, Liu C, Wang C, Guo J. Transcriptomic analysis of the porcine endometrium during embryo implantation. Genes. 2015;6(4):1330-46. http://dx.doi.org/10.3390/genes6041330. PMid:26703736. 
Liu L, Liu X, Ren X, Tian Y, Chen Z, Xu X, Du Y, Jiang C, Fang Y, Liu Z, Fan B, Zhang Q, Jin G, Yang X, Zhang X. Smad2 and Smad3 have differential sensitivity in relaying TGF $\beta$ signaling and inversely regulate early lineage specification. Sci Rep. 2016;6(1):21602. http://dx.doi.org/10.1038/srep21602. PMid:26905010.

López-Rodriguez A, Rijsselaere T, Beek J, Vyt P, Van Soom A, Maes D. Boar seminal plasma components and their relation with semen quality. Syst Biol Reprod Med. 2013;59(1):5-12. http://dx.doi.org/10.3109/19396368.2012.725120. PMid:23083319.

Maegawa M, Kamada M, Irahara M, Yamamoto S, Yoshikawa S, Kasai Y, Ohmoto Y, Gima H, Thaler CJ, Aono T. A repertoire of cytokines in human seminal plasma. J Reprod Immunol. 2002;54(1-2):33-42. http://dx.doi.org/10.1016/S0165-0378(01)00063-8. PMid:11839394.

Mains LM, Christenson L, Yang B, Sparks AE, Mathur S, Van Voorhis BJ. Identification of apolipoprotein A1 in the human embryonic secretome. Fertil Steril. 2011;96(2):422-7.e2. http://dx.doi.org/10.1016/j.fertnstert.2011.05.049. PMid:21676393.

Mann T, Leone E. Studies on the metabolism of semen. VIII. Ergothioneine as a normal constituent of boar seminal plasma; purification and crystallization; site of formation and function. Biochem J. 1953;53(1):140-8. http://dx.doi.org/10.1042/bj0530140. PMid:13032046.

Mann T, Lutwak-Mann C. Biochemistry of seminal plasma and male accessory fluids; application to andrological problems. In: Mann T, Lutwak-Mann C, editors. Male reproductive function and semen. Berlin: Springer-Verlag; 1981. Chapter IX; p. 269-326. http://dx.doi.org/10.1007/978-1-4471-1300-3_9.

Marin S, Chiang K, Bassilian S, Lee WN, Boros LG, Fernandez-Novell JM, Centelles JJ, Medrano A, Rodriguez-Gil JE, Cascante M. Metabolic strategy of boar spermatozoa revealed by a metabolomic characterization. FEBS Lett. 2003;554(3):342-6. http://dx.doi.org/10.1016/S0014-5793(03)01185-2. PMid:14623091.

Martinez CA, Cambra JM, Nohalez A, Parrilla I, Roca J, Vazquez JL, Rodriguez-Martinez H, Gil MA, Martinez EA, Cuello C. Prevention of hatching of porcine morulae and blastocysts by liquid storage at $20^{\circ} \mathrm{C}$. Sci Rep. 2019a;9(1):6219. http://dx.doi.org/10.1038/s41598-019-42712-x. PMid:30996298.

Martinez CA, Cambra JM, Nohalez A, Parrilla I, Sanchez-Osorio J, Roca J, Rodriguez-Martinez H, Gil MA, Martinez EA, Cuello C. Porcine blastocyst viability and developmental potential is maintained for $48 \mathrm{~h}$ of liquid storage at $25^{\circ} \mathrm{C}$ without CO2 gassing. Theriogenology. 2019b;135:46-55. http://dx.doi.org/10.1016/j.theriogenology.2019.06.003. PMid:31200096.

Martinez CA, Cambra JM, Parrilla I, Roca J, Ferreira-Dias G, Pallares FJ, Lucas X, Vazquez JM, Martinez EA, Gil MA, Rodriguez-Martinez H, Cuello C, Alvarez-Rodriguez M. Seminal plasma modifies the transcriptional pattern of the endometrium and advances embryo development in pigs. Front Vet Sci. 2019c;6:465. http://dx.doi.org/10.3389/fvets.2019.00465. PMid:31921921.

Martinez EA, Angel MA, Cuello C, Sanchez-Osorio J, Gomis J, Parrilla I, Vila J, Colina I, Diaz M, Reixach J, Vazquez JL, Vazquez JM, Roca J, Gil MA. Successful non-surgical deep uterine transfer of porcine morulae after 24 hour culture in a chemically defined medium. PLoS One. 2014;9(8):e104696. http://dx.doi.org/10.1371/journal.pone.0104696. PMid:25118944.

Martinez EA, Martinez CA, Cambra JM, Maside C, Lucas X, Vazquez JL, Vazquez JM, Roca J, RodriguezMartinez H, Gil MA, Parrilla I, Cuello C. Achievements and future perspectives of embryo transfer technology in pigs. Reprod Domest Anim. 2019d;54(Suppl 4):4-13. http://dx.doi.org/10.1111/rda.13465. PMid:31625238.

Martinez EA, Martinez CA, Nohalez A, Sanchez-Osorio J, Vazquez JM, Roca J, Parrilla I, Gil MA, Cuello C. Nonsurgical deep uterine transfer of vitrified, in vivo-derived, porcine embryos is as effective as the default surgical approach. Sci Rep. 2015;5(1):10587. http://dx.doi.org/10.1038/srep10587. PMid:26030839.

Maxwell WM, Johnson LA. Physiology of spermatozoa at high dilution rates: the influence of seminal plasma. Theriogenology. 1999;52(8):1353-62. http://dx.doi.org/10.1016/S0093-691X(99)00222-8. PMid:10735081.

McBride A, Ghilagaber S, Nikolaev A, Hardie DG. The glycogen-binding domain on the AMPK beta subunit allows the kinase to act as a glycogen sensor. Cell Metab. 2009;9(1):23-34. http://dx.doi.org/10.1016/j.cmet.2008.11.008. PMid:19117544.

Ming Q, Roske Y, Schuetz A, Walentin K, Ibraimi I, Schmidt-Ott KM, Heinemann U. Structural basis of gene regulation by the Grainyhead/CP2 transcription factor family. Nucleic Acids Res. 2018;46(4):2082-95. http://dx.doi.org/10.1093/nar/gkx1299. PMid:29309642.

Mogielnicka-Brzozowska M, Kordan W. Characteristics of selected seminal plasma proteins and their application in the improvement of the reproductive processes in mammals. Pol J Vet Sci. 2011;14(3):489-99. http://dx.doi.org/10.2478/v10181-011-0074-z. PMid:21957748. 
Morris D, Diskin M. Effect of progesterone on embryo survival. Animal. 2008;2(8):1112-9. http://dx.doi.org/10.1017/S1751731108002474. PMid:22443722.

Murer V, Spetz JF, Hengst U, Altrogge LM, de Agostini A, Monard D. Male fertility defects in mice lacking the serine protease inhibitor protease nexin-1. Proc Natl Acad Sci USA. 2001;98(6):3029-33. http://dx.doi.org/10.1073/pnas.051630698. PMid:11248026.

Nayeem SB, Arfuso F, Dharmarajan A, Keelan JA. Role of Wnt signalling in early pregnancy. Reprod Fertil Dev. 2016;28(5):525-44. http://dx.doi.org/10.1071/RD14079. PMid:25190280.

Nikodemus D, Lazic D, Bach M, Bauer T, Pfeiffer C, Wiltzer L, Lain E, Schömig E, Gründemann D. Paramount levels of ergothioneine transporter SLC22A4 mRNA in boar seminal vesicles and crossspecies analysis of ergothioneine and glutathione in seminal plasma. J Physiol Pharmacol. 2011;62(4):411-9. PMid:22100842.

Novak S, Ruiz-Sanchez A, Dixon WT, Foxcroft GR, Dyck MK. Seminal plasma proteins as potential markers of relative fertility in boars. J Androl. 2010;31(2):188-200. http://dx.doi.org/10.2164/jandrol.109.007583. PMid:19713565.

O WS, Chen HQ, Chow PH. Effects of male accessory sex gland secretions on early embryonic development in the golden hamster. J Reprod Fertil. 1988;84(1):341-4. http://dx.doi.org/10.1530/jrf.0.0840341. PMid:3184052.

O'Leary S, Jasper MJ, Robertson SA, Armstrong DT. Seminal plasma regulates ovarian progesterone production, leukocyte recruitment and follicular cell responses in the pig. Reproduction. 2006;132(1):147-58. http://dx.doi.org/10.1530/rep.1.01119. PMid:16816340.

O'Leary S, Jasper MJ, Warnes GM, Armstrong DT, Robertson SA. Seminal plasma regulates endometrial cytokine expression leukocyte recruitment and embryo development in the pig. Reproduction. 2004;128(2):237-47. http://dx.doi.org/10.1530/rep.1.00160. PMid:15280563.

O'Neill C. The potential roles for embryotrophic ligands in preimplantation embryo development. Hum Reprod Update. 2008;14(3):275-88. http://dx.doi.org/10.1093/humupd/dmn002. PMid:18281694.

Pang SF, Chow PH, Wong TM. The role of the seminal vesicle, coagulating glands and prostate glands on the fertility and fecundity of mice. J Reprod Fertil. 1979;56(1):129-32. http://dx.doi.org/10.1530/jrf.0.0560129. PMid:469833.

Parrilla I, Pérez-Patiño C, Li J, Barranco I, Padilla L, Rodriguez-Martinez H, Martinez EA, Roca J. Boar semen proteomics and sperm preservation. Theriogenology. 2019;137:23-9. http://dx.doi.org/10.1016/j.theriogenology.2019.05.033. PMid:31208776.

Parrilla I, Vazquez JM, Caballero I, Gil MA, Hernandez M, Roca J, Lucas X, Martinez EA. Optimal characteristics of spermatozoa for semen technologies in pigs. In: Rodriguez-Martinez H, Vallet JL, Ziecik AJ, editors. Control of pig reproduction VIII. Nottingham: Nottingham University Press; 2009. p. 37-50.

Pérez-Patiño C, Barranco I, Parrilla I, Valero ML, Martinez EA, Rodriguez-Martinez H, Roca J. Characterization of the porcine seminal plasma proteome comparing ejaculate portions. J Proteomics. 2016;142:15-23. http://dx.doi.org/10.1016/j.jprot.2016.04.026. PMid:27109353.

Peitz B, Olds Clarke P. Effects of seminal vesicle removal on fertility and uterine sperm motility in the house mouse. Biol Reprod. 1986;35(3):608-17. http://dx.doi.org/10.1095/biolreprod35.3.608. PMid:3790662.

Pérez-Patiño C, Parrilla I, Li J, Barranco I, Martinez EA, Rodriguez-Martinez H, Roca J. The proteome of pig spermatozoa is remodeled during ejaculation. Mol Cell Proteomics. 2019;18(1):41-50. http://dx.doi.org/10.1074/mcp.RA118.000840. PMid:30257877.

Petrof G, Nanda A, Howden J, Takeichi T, McMillan JR, Aristodemou S, Ozoemena L, Liu L, South AP, Pourreyron C, Dafou D, Proudfoot LE, Al-Ajmi H, Akiyama M, McLean WH, Simpson MA, Parsons M, McGrath JA. Mutations in GRHL2 result in an autosomal-recessive ectodermal dysplasia syndrome. Am J Hum Genet. 2014;95(3):308-14. http://dx.doi.org/10.1016/j.ajhg.2014.08.001. PMid:25152456.

Pipan MZ, Mrkun J, Strajn BJ, Vrtač KP, Kos J, Pišlar A, Zrimšek P. The influence of macro- and microelements in seminal plasma on diluted boar sperm quality. Acta Vet Scand. 2017;59(1):11. http://dx.doi.org/10.1186/s13028-017-0279-y. PMid:28187743.

Pursel VG, Johnson LA. Freezing of boar spermatozoa: fertilizing capacity with concentrated semen and a new thawing procedure. J Anim Sci. 1975;40(1):99-102. http://dx.doi.org/10.2527/jas1975.40199x. PMid:1110222. 
Qazi IH, Angel C, Yang H, Zoidis E, Pan B, Wu Z, Ming Z, Zeng CJ, Meng Q, Han H, Zhou G. Role of selenium and selenoproteins in male reproductive function: a review of past and present evidences. Antioxidants. 2019;8(8):268. http://dx.doi.org/10.3390/antiox8080268. PMid:31382427.

Qiu Q, Yang M, Tsang BK, Gruslin A. EGF-induced trophoblast secretion of MMP-9 and TIMP-1 involves activation of both PI3K and MAPK signalling pathways. Reproduction. 2004;128(3):355-63. http://dx.doi.org/10.1530/rep.1.00234. PMid:15333786.

Queen K, Dhabuwala CB, Pierrepoint CG. The effect of removal of the various accessory sex glands on the fertility of male rats. J Reprod Fertil. 1981;62(2):423-6. http://dx.doi.org/10.1530/jrf.0.0620423. PMid:7252923.

Radomil L, Pettitt MJ, Merkies KM, Hickey KD, Buhr MM. Stress and dietary factors modify boar sperm for processing. Reprod Domest Anim. 2011;46(Suppl 2):39-44. http://dx.doi.org/10.1111/j.14390531.2011.01865.x. PMid:21884275.

Robertson SA, Moldenhauer LM. Immunological determinants of implantation success. Int J Dev Biol. 2014;58(2-4):205-17. http://dx.doi.org/10.1387/ijdb.140096sr. PMid:25023687.

Robertson SA. GM-CSF regulation of embryo development and pregnancy. Cytokine Growth Factor Rev. 2007;18(3-4):287-98. http://dx.doi.org/10.1016/j.cytogfr.2007.04.008. PMid:17512774.

Robertson SA. Immune regulation of conception and embryo implantation-all about quality control? J Reprod Immunol. 2010;85(1):51-7. http://dx.doi.org/10.1016/j.jri.2010.01.008. PMid:20347158.

Robertson SA. Seminal plasma and male factor signaling in the female reproductive tract. Cell Tissue Res. 2005;322(1):43-52. http://dx.doi.org/10.1007/s00441-005-1127-3. PMid:15909166.

Roca J, Broekhuijse MLWJ, Parrilla I, Rodriguez-Martinez H, Martinez EA, Bolarin A. Boar differences in artificial insemination outcomes: can they be minimized. Reprod Domest Anim. 2015;50(Suppl 2):4855. http://dx.doi.org/10.1111/rda.12530. PMid:26174919.

Roca J, Pérez-Patiño C, Barranco I, Padilla LC, Martinez EA, Rodriguez-Martinez H, Parrilla I. Proteomics in fresh and preserved pig semen: recent achievements and future challenges. Theriogenology. 2020. In press. http://dx.doi.org/10.1016/j.theriogenology.2020.01.066.

Roca J, Rodríguez MJ, Gil MA, Carvajal G, Garcia EM, Cuello C, Vazquez JM, Martinez EA. Survival and in vitro fertility of boar spermatozoa frozen in the presence of superoxide dismutase and/or catalase. J Androl. 2005;26(1):15-24. http://dx.doi.org/10.1002/j.1939-4640.2005.tb02867.xPMid:15611562. PMid:15611562.

Rodríguez-Gil JE. Energy management of mature mammalian spermatozoa. In: Lemma A, editor. Success in artificial insemination: quality of semen and diagnostics employed. Croatia: IntechOpen; 2013. http://dx.doi.org/10.5772/51711.

Rodriguez-Martinez H, Kvist U, Saravia F, Wallgren M, Johannisson A, Sanz L, Peña FJ, Martinez EA, Roca J, Vazquez JM, Calvete JJ. The physiological roles of the boar ejaculate. In: Rodriguez-Martinez H, Vallet JL, Ziecik AJ, editors. Control of pig reproduction VIII. Nottingham: Nottingham University Press; 2009. p. 1-21.

Rodríguez-Martínez, Kvist U, Ernerudh J, Sanz L, Calvete JJ. Seminal plasma proteins: what role do they play? Am J Reprod Immunol. 2011;66(Suppl 1):11-22. http://dx.doi.org/10.1111/j.16000897.2011.01033.x. PMid:21726334.

Rudensky AY. Regulatory T cells and Foxp3. Immunol Rev. 2011;241(1):260-8. http://dx.doi.org/10.1111/j.1600-065X.2011.01018.x. PMid:21488902.

Saba-El-Leil MK, Vella FD, Vernay B, Voisin L, Chen L, Labrecque N, Ang SL, Meloche S. An essential function of the mitogen-activated protein kinase Erk2 in mouse trophoblast development. EMBO Rep. 2003;4(10):964-8. http://dx.doi.org/10.1038/sj.embor.embor939. PMid:14502223.

Samborski A, Graf A, Krebs S, Kessler B, Bauersachs S. Deep sequencing of the porcine endometrial transcriptome on day 14 of pregnancy. Biol Reprod. 2013;88(4):84. http://dx.doi.org/10.1095/biolreprod.113.107870. PMid:23426436.

Santamaría D, Barrière C, Cerqueira A, Hunt S, Tardy C, Newton K, Cáceres JF, Dubus P, Malumbres M, Barbacid M. Cdk1 is sufficient to drive the mammalian cell cycle. Nature. 2007;448(7155):811-5. http://dx.doi.org/10.1038/nature06046. PMid:17700700.

Saravia F, Wallgren M, Johannisson A, Calvete JJ, Sanz L, Peña FJ, Roca J, Rodriguez-Martinez H. Exposure to the seminal plasma of different portions of the boar ejaculate modulates the survival of spermatozoa cryopreserved in MiniFlatPacks. Theriogenology. 2009;71(4):662-75. http://dx.doi.org/10.1016/j.theriogenology.2008.09.037. PMid:18952274. 
Schjenken JE, Robertson SA. Seminal fluid and immune adaptation for pregnancy - comparative biology in mammalian species. Reprod Domest Anim. 2014;49(Suppl 3):27-36. http://dx.doi.org/10.1111/rda.12383. PMid:25220746.

Schuberth HJ, Taylor U, Zerbe H, Waberski D, Hunter R, Rath D. Immunological responses to semen in the female genital tract. Theriogenology. 2008;70(8):1174-81. http://dx.doi.org/10.1016/j.theriogenology.2008.07.020. PMid:18757083.

Scott MP, Carroll SB. The segmentation and homeotic gene network in early Drosophila development. Cell. 1987;51(5):689-98. http://dx.doi.org/10.1016/0092-8674(87)90092-4. PMid:2890437.

Setchell BP, Brooks DE. Anatomy, vasculature, innervation and fluids of the male reproductive tract. In: Knobil E, Neil J, editors. The physiology of reproduction. New York: Raven Press; 1988. p. 753-836. (vol. 2).

Shevach EM. CD4+CD25+ suppressor T cells: more questions than answers. Nat Rev Immunol. 2002;2(6):389-400. http://dx.doi.org/10.1038/nri821. PMid:12093005.

Shiota C, Woo J-T, Lindner J, Shelton KD, Magnuson MA. Multiallelic disruption of the Rictor gene in mice reveals that mTOR complex 2 is essential for fetal growth and viability. Dev Cell. 2006;11(4):583-9. http://dx.doi.org/10.1016/j.devcel.2006.08.013. PMid:16962829.

Sjöblom C, Roberts CT, Wikland M, Robertson SA. Granulocyte-macrophage colony-stimulating factor alleviates adverse consequences of embryo culture on fetal growth trajectory and placental morphogenesis. Endocrinology. 2005;146(5):2142-53. http://dx.doi.org/10.1210/en.2004-1260. PMid:15705781.

Sjöblom C, Wikland M, Robertson SA. Granulocyte-macrophage colony-stimulating factor (GM-CSF) acts independently of the beta common subunit of the GM-CSF receptor to prevent inner cell mass apoptosis in human embryos. Biol Reprod. 2002;67(6):1817-23. http://dx.doi.org/10.1095/biolreprod.101.001503. PMid:12444058.

Songyang Z, Baltimore D, Cantley LC, Kaplan DR, Franke TF. Interleukin 3-dependent survival by the Akt protein kinase. Proc Natl Acad Sci USA. 1997;94(21):11345-50. http://dx.doi.org/10.1073/pnas.94.21.11345. PMid:9326612.

Sopkova D, Andrejcakova Z, VIckova R, Danisova O, Supuka P, Ondrasovicova S, Petrilla V. Lactate dehydrogenase as a possible indicator of reproductive capacity of boars. Indian J Anim Sci. 2015;85(2):143-7.

Sun R, Lei L, Liu S, Xue B, Wang J, Wang J, Shen J, Duan L, Shen X, Cong Y, Gu Y, Hu K, Jin L, Liu ZH. Morphological changes and germ layer formation in the porcine embryos from days 7-13 of development. Zygote. 2015;23(2):266-76. http://dx.doi.org/10.1017/S0967199413000531. PMid:24229742.

Syriou V, Papanikolaou D, Kozyraki A, Goulis DG. Cytokines and Male Infertility. Eur Cytokine Netw. 2018;29(3):73-82. http://dx.doi.org/10.1684/ecn.2018.0412. PMid:30547889.

Taams LS, Akbar AN. Peripheral generation and function of CD4+CD25+ regulatory T cells. Curr Top Microbiol Immunol. 2005;293:115-31. http://dx.doi.org/10.1007/3-540-27702-1_6. PMid:15981478.

Troedsson MH, Desvousges A, Alghamdi AS, Dahms B, Dow CA, Hayna J, Valesco R, Collahan PT, Macpherson ML, Pozor M, Buhi WC. Components in seminal plasma regulating sperm transport and elimination. Anim Reprod Sci. 2005;89(1-4):171-86. http://dx.doi.org/10.1016/j.anireprosci.2005.07.005. PMid:16102920.

Vilagran I, Yeste M, Sancho S, Casas I, Rivera del Álamo MM, Bonet S. Relationship of sperm small heatshock protein 10 and voltage-dependent anion channel 2 with semen freezability in boars. Theriogenology. 2014;82(3):418-26. http://dx.doi.org/10.1016/j.theriogenology.2014.04.023. PMid:24933094.

Waberski D, Claassen R, Hahn T, Jungblut PW, Parvizi N, Kallweit E, Weitze KF. LH profile and advancement of ovulation after transcervical infusion of seminal plasma at different stages of oestrus in gilts. J Reprod Fertil. 1997;109(1):29-34. http://dx.doi.org/10.1530/jrf.0.1090029. PMid:9068410.

Waberski D, Schäfer J, Bölling A, Scheld M, Henning H, Hambruch N, Schuberth H-J, Pfarrer C, Wrenzycki C, Hunter RHF. Seminal plasma modulates the immune-cytokine network in the porcine uterine tissue and pre-ovulatory follicles. PLoS One. 2018;13(8):e0202654. http://dx.doi.org/10.1371/journal.pone.0202654. PMid:30153288. 
Waclawik A, Kaczmarek M, Blitek A, Kaczynski P, Ziecik AJ. Embryo-maternal dialogue during pregnancy establishment and implantation in the pig. Mol Reprod Dev. 2017;84(9):842-55. http://dx.doi.org/10.1002/mrd.22835. PMid:28628266.

Watson JG, Carroll J, Chaykin S. Reproduction in mice: the fate of spermatozoa not involved in fertilization. Gamete Res. 1983;7(1):75-84. http://dx.doi.org/10.1002/mrd.1120070107.

Wysocki P, Strzezek J. Molecular forms of acid phosphatase of boar seminal plasma. Anim Sci Pap Rep. 2000;18(2):99-106.

Yao Y, Li W, Wu J, Germann UA, Su MS, Kuida K, Boucher DM. Extracellular signal-regulated kinase 2 is necessary for mesoderm differentiation. Proc Natl Acad Sci USA. 2003;100(22):12759-64. http://dx.doi.org/10.1073/pnas.2134254100. PMid:14566055.

Yeste M, Rodriguez-Gil JE, Bonet S. Artificial insemination with frozen-thawed boar sperm. Mol Reprod Dev. 2017;84(9):802-13. http://dx.doi.org/10.1002/mrd.22840. PMid:28608609.

Yong HEJ, Murthi P, Kalionis B, Keogh RJ, Brennecke SP. Decidual ACVR2A regulates extravillous trophoblast functions of adhesion, proliferation, migration and invasion in vitro. Pregnancy Hypertens. 2018;12:189-93. http://dx.doi.org/10.1016/j.preghy.2017.11.002. PMid:29203340.

\section{Author contributions}

IP: Conceptualization, Writing - original draft, Supervision, Visualization, Validation, Writing - review \& editing; EAM: Conceptualization, Writing - original draft, Supervision, Visualization, Validation, Writing - review \& editing; MAG: Validation; CC: Validation; JR: Validation; HRM: Visualization, Validation, Writing - review \& editing; CAM: Conceptualization, Writing - original draft, Supervision, Visualization, Validation, Writing - review \& editing. 